\begin{tabular}{|c|c|c|}
\hline & \begin{tabular}{c} 
International Journal of Current Research in \\
Biosciences and Plant Biology \\
\hline PXCELLENT \\
PUBLISHERS
\end{tabular} \\
Volume $4 \bullet$ Number 7 (July-2017) $\bullet$ ISSN: 2349-8080 (Online) \\
Journal homepage: www.ijcrbp.com
\end{tabular}

\title{
Effect of Different Levels of NPK in Combination with Rhizobium and PSB Culture on Growth Performance of Green Gram (Vigna radiata L. Wilczek) under Subabul (Leucaena leucocephala) based Agrisilviculture Systems
}

\author{
Deepak Kumar Chauhan* and Rajiv Umrao
}

School of Forestry and Environment, Sam Higginbottom Institute of Agriculture, Technology and Sciences (SHIATS), Deemed to be University, Allahabad, Uttar Pradesh-211 007, India

\section{*Corresponding author.}

\begin{abstract}
The experiment was laid out during summer season of 2015 at Forest Nursery, School of Forestry and Environment, SHIATS, Allahabad, UP, India to study the effect of different levels of NPK in combination with Rhizobium and PSB culture on growth of green gram (Vigna radiata L. Wilczek) under subabul (Leucaena leucocephala) based agroforestry system. The subabul was planted at a spacing of $8 \times 1$ meter and green gram was sown under subabul based agroforestry system. The experiment was conducted in randomized block design having three levels of $\mathrm{N}+\mathrm{P}+\mathrm{K}$ and seed inoculated by strain Rhizobium (MOR-1) and Phosphate Solubilising Bacteria (Bacillus subtilis) of Green gram (Vigna radiata $\mathrm{L}$. Wilczek.) with three replications. The inoculants were obtained from the Department of the Agroforestry, School of Forestry and Environment, SHIIATS, Allahabad. The treatments were randomized as per statistical procedure. Experiment consisted of total 9 treatment combinations: $\mathrm{T}_{1}$-Control, $\mathrm{T}_{2}-20-20-10 \mathrm{~kg} \mathrm{NPK} / \mathrm{ha}, \mathrm{T}_{3}-30-$ 30-15 kg NPK/ha, $\mathrm{T}_{4^{-}}$40-40-20 kg NPK/ha, $\mathrm{T}_{5^{-}}$50-50-25 kg NPK/ha, $\mathrm{T}_{6^{-}}-20-20-10 \mathrm{~kg}$ $\mathrm{NPK} / \mathrm{ha}+$ Rhizobium and PSB culture, $\mathrm{T}_{7-}$ 30-30-15 kg NPK/ha+ Rhizobium and PSB culture, $\mathrm{T}_{8^{-}}$40-40-20 kg NPK/ha+ Rhizobium and PSB culture and $\mathrm{T}_{9^{-}} 50-50-25 \mathrm{~kg}$ NPK/ha+ Rhizobium and PSB Culture. The result revealed that during summer season green gram cultivar of cv. HUM-16 performed best fertilized with $\left(\mathrm{T}_{7}-30-30-15 \mathrm{~kg}\right.$ NPK/ha) with dual seed inoculation of rhizobium and PSB culture. This treatment combination found more productive and economical, which closely followed by the treatment combination of $\left(\mathrm{T}_{4}-40-40-20 \mathrm{~kg} \mathrm{NPK} / \mathrm{ha}\right)$.
\end{abstract}

\section{Introduction}

Agroforestry as a land use system that integrates trees, crops and animals in a way that it is scientifically sound, ecologically desirable, practically feasible and socially acceptable to the farmers (Nair, 1979). Subabul

\author{
Article Info \\ Accepted: 30 June 2017 \\ Available Online: 06 July 2017 \\ Keywords \\ Green gram \\ Inorganic fertilizer \\ Phosphate solubilising bacteria \\ Rhizobium \\ Subabul
}


globular and the flower are white. Green gram (Vigna radiata $\mathrm{L}$. Wilczek) belongs to the family of Fabaceae. It is also known as mung or golden gram. It's native to the Indian subcontinent. Apart from India it is also cultivated in china, Thailand, Indonesia, Burma, Bangladesh and also in hot and dry region of southern Europe and southern United States. In India; green gram occupies 3.44 million hectares and contributes to 1.45 million metric tons in pulse production.

Nitrogen requirement of pulses is very low than other crops because nitrogen is needed only for establishment of plant, later on plants have their own potentiality to fulfill their requirement through symbiotic nitrogen fixation. Nitrogen is an essential element for proper plant growth and development. It imparts green colour to leaves and stems and enables them for efficient photosynthesis.

Phosphorus is associated with several vital functions like seed germination, cell division, flowering, fruiting, and synthesis of fat, starch and in almost every biochemical activities.

Potassium is the third macro nutrient required for plant growth, after nitrogen and phosphorus and also plays a vital role as macronutrient in plant growth and sustainable crop production. Its adequate supply during growth period improves the water relations of plant and photosynthesis, synthesizes the protein and creates resistance against the pest attack and diseases. Water deficit is frequently the primary limiting factor for crop production under arid and semi-arid conditions (Hussain et al., 2011).

Bio-fertilizers are organic products containing living cells of different types of microorganisms, which have the ability to convert nutritionally important elements from unavailable to available form through biological processes (Vessey, 2003). They are often used for composting the area with the objective of increasing the number of such micro- organisms and accelerate microbial activities to augment the extant of the availability of the nutrient in a form which can easily assimilated by plant (Subba Rao, 1986).

The Rhizobium as fertilizer in pulses could fix $50-200 \mathrm{~kg}$ of $\mathrm{N} \mathrm{ha}^{-1}$ season $^{-1}$ and is able to meet 80-90 percent of the crop requirement for nitrogen. Inoculation in these crops was found to increase the crop yield by about 1015 per cent under on farm conditions (Khurana and
Dudeja, 1997). In many situations this association also leaves substantial residual nitrogen for subsequent crops. Nitrogen fixation by different annual legumes has been reported to vary from $35-270 \mathrm{~kg} \mathrm{~N} \mathrm{ha}{ }^{-1} \mathrm{Yr}^{-1}$ (Nutman, 1969). Inoculation of seeds with Rhizobium culture is a very low cost method of nitrogen fertilization in legume and has been found beneficial.

\section{Materials and methods}

A field trail was conducted during summer season of 2015 at the Forest Nursery, School of Forestry and Environment, SHIATS Allahabad. To study the effect of NPK level in combination with Rhizobium and PSB culture on growth of green gram (Vigna radiata L. Wilczek) under the subabul (Leucaena leucocephala) based agroforestry system. Nine treatment combination consisting of on variety viz., HUM-16, Four level of inorganic fertilizer and including control (F1: 20-20-10, F2: 30-30-15, F3: 40-40-20, F4: 50-50-25) and seed inoculation with Rhizobium (MOR-1) and Phosphorus solubilizing bacteria (PSB) were evaluated in Randomized block design. The result revealed that during summer season green gram cultivar of cv. HUM16 performed best fertilized with (T7:30-30-15 kg NPK/ha) with dual seed inoculation of Rhizobium and PSB culture. This treatment combination fount more productive and economical, which closely followed by the treatment combination of (T4:40-40-20 kg NPK/ha). The seeds of mung bean were sown on 01 April 2015 in row having a depth of $2-3 \mathrm{~cm}$. Row to row distance was $30 \mathrm{~cm}$. The thinning was done at 15 day after sowing (DAS) to maintain $10 \mathrm{~cm}$ between plant to plant distances in each row. The crop field was weeded at 20 and 30 DAS. Irrigation was done as per requirement. Harvesting was done when $90 \%$ of pods become brown to black in colour. Five plants from each plot were randomly selected to the study of plant height $(\mathrm{cm})$, number of trifoliate leaves per plant and number of pods per plant.

\section{Results and discussion}

\section{Number of root nodules per plant}

From Table 1 and Fig. 1, it was observed that the number of root nodules per plant was significantly influenced by different treatment combinations at different NPK levels in combination with Rhizobium and PSB culture. At 25 DAS it was observed that different treatment combination did significantly affect the 
number of root nodules per plant. The maximum number of root nodules per plant was found in treatment $\mathrm{T}_{7}$ (22.4) followed by treatment $\mathrm{T}_{6}$ (19.93) in open condition and minimum number of root nodules per plant was observed in $\mathrm{T}_{1}(11.07)$.

Maximum number of root nodules per plant under subabul based agroforestry system is found in $\mathrm{T}_{7}$ (15.14), followed by $\mathrm{T}_{6}$ (13.07) and the minimum number of root nodules was observed in $\mathrm{T}_{1}(5.14 \mathrm{~cm})$. At
50 DAS, it was observed that different treatment combination significantly affect the number of root nodules per plant. The maximum root nodules per plant was found in treatment $T_{7}$ (30.8) followed by treatment $\mathrm{T}_{6}$ (27.6) and minimum root nodules per plant was observed in $\mathrm{T}_{1}$ (18.8). Maximum number of root nodules per plant under subabul based agroforestry system is found in $\mathrm{T}_{7}$ (19.36), followed by $\mathrm{T}_{6}$ (18.2) and the minimum number of root nodules per plant was observed in $\mathrm{T}_{1}(10.14)$.

Table 1. Effect of N P K level in combination with Rhizobium and PSB culture on Number of root nodules per plant of green gram under subabul based agroforestry system.

\begin{tabular}{|c|c|c|c|c|}
\hline \multirow{3}{*}{ Treatment } & \multicolumn{4}{|c|}{ Number of root nodules per plant } \\
\hline & \multicolumn{2}{|l|}{ Shade condition } & \multicolumn{2}{|c|}{ Open condition } \\
\hline & 25 DAS & 50 DAS & 25 DAS & 50 DAS \\
\hline T1 & 5.14 & 10.14 & 11.07 & 18.8 \\
\hline T2 & 8.0 & 13.0 & 12.27 & 20.87 \\
\hline T3 & 9.14 & 14.2 & 14.4 & 22.0 \\
\hline T4 & 10.34 & 16.07 & 15.6 & 24.07 \\
\hline T5 & 12.0 & 17.54 & 18.14 & 26.6 \\
\hline T6 & 13.07 & 18.2 & 19.93 & 27.6 \\
\hline T7 & 15.14 & 19.36 & 22.4 & 30.8 \\
\hline T8 & 11.67 & 14.94 & 13.8 & 24.94 \\
\hline T9 & 11.47 & 15.87 & 15.4 & 25.6 \\
\hline T test & $\mathbf{S}$ & $\mathbf{S}$ & $\mathbf{S}$ & $\mathbf{S}$ \\
\hline SEM $( \pm)$ & 0.3241323 & 0.4525061 & 0.5912949 & 0.5817173 \\
\hline CD $(0.5 \%)$ & 0.6871604 & 0.9593128 & 1.2535451 & 1.2332408 \\
\hline
\end{tabular}

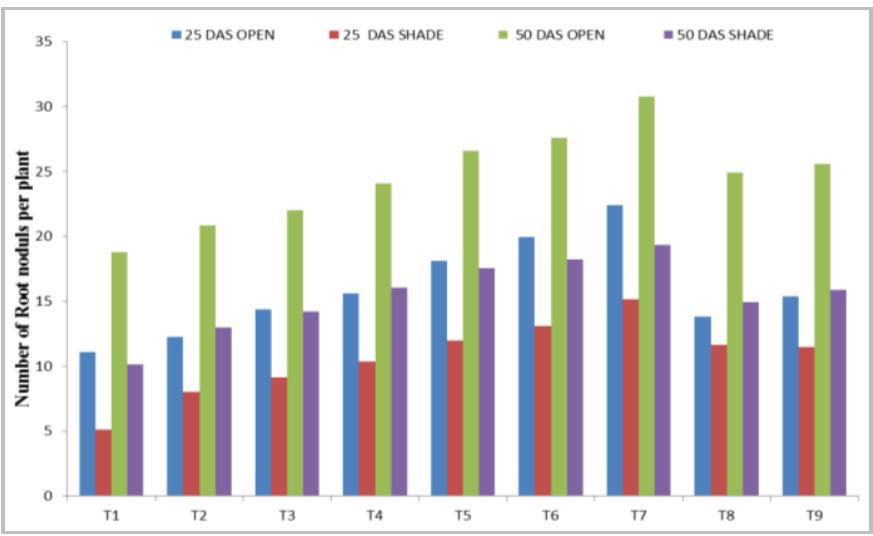

Fig. 1: Effect of N P K level in combination with Rhizobium and PSB culture on Number of Root nodules per plant of green gram under Subabul based Agroforestry system.

\section{Number of trifoliate leaves per plant}

From the Table 2 and Fig. 2 it was observed that the plant height $(\mathrm{cm})$ was significantly influenced by different treatment combinations at different NPK level in combination with Rhizobium and PSB culture. At 25 DAS, it was observed that different treatment combination did significantly affect the number of trifoliate leaves per plant. The maximum number of trifoliate leaves per plant was found in treatment $\mathrm{T}_{7}$ (10.14) followed by treatment T4 (8.6) in open condition and minimum number of trifoliate leaves per plant was observed in $T_{1}$ (4.0). Maximum number of trifoliate leaves per plant under subabul based agroforestry system is found in $T_{7}(7.87)$, followed by $T_{4}(6.34)$ and the minimum Trifoliate leaves per plant was observed in $\mathrm{T}_{1}(2.6)$.

At 50 DAS, it was observed that different treatment combination significantly affect the number of trifoliate leaves per plant. The maximum number of trifoliate leaves per plant was found in treatment $\mathrm{T}_{7}$ (12.07) followed by treatment $\mathrm{T}_{4}$ (11.0) and minimum number of trifoliate leaves per plant was observed in $\mathrm{T}_{1}$ (6.42). Maximum number of trifoliate leaves per plant under subabul based agroforestry system is found in $\mathrm{T}_{7}$ (11.4), followed by $\mathrm{T}_{4}$ (10.8) and the minimum number of trifoliate leaves per plant was observed in $\mathrm{T}_{1}$ (5.07). At 75 DAS, it was observed that different treatment combination significantly affect the number of trifoliate 
leaves per plant. The maximum number of trifoliate leaves per plant was found in treatment $\mathrm{T}_{7}$ (10.2) followed by treatment $\mathrm{T}_{4}(9.14)$ and minimum number of trifoliate leaves per plant was observed in $\mathrm{T}_{1}$ (5.47).
Maximum number of trifoliate leaves per plant under subabul based agroforestry system is found in $\mathrm{T}_{7}$ (10.23), followed by $\mathrm{T}_{4}$ (8.24) and the minimum number of trifoliate leaves per plant was observed in $\mathrm{T}_{1}(4.07 \mathrm{~cm})$.

Table 2. Effect of N P K level in combination with Rhizobium and PSB culture in number of trifoliate leaves per plant on of green gram under Subabul based Agroforestry system.

\begin{tabular}{|c|c|c|c|c|c|c|}
\hline \multirow{3}{*}{ Treatment } & \multicolumn{6}{|c|}{ Number of trifoliate leaves per plant } \\
\hline & \multicolumn{3}{|c|}{ Shade condition } & \multicolumn{3}{|c|}{ Open condition } \\
\hline & 25 DAS & 50 DAS & 75 DAS & 25 DAS & 50 DAS & 75 DAS \\
\hline T1 & 2.6 & 5.07 & 4.07 & 4.0 & 6.24 & 5.47 \\
\hline $\mathbf{T 2}$ & 3.14 & 6.8 & 5.47 & 5.47 & 7.47 & 7.2 \\
\hline T3 & 5.0 & 8.8 & 7.2 & 7.4 & 9.2 & 8.34 \\
\hline T4 & 6.34 & 10.8 & 8.27 & 8.6 & 11.0 & 8.4 \\
\hline T5 & 4.27 & 8.0 & 6.4 & 6.94 & 8.34 & 7.94 \\
\hline T6 & 5.94 & 9.14 & 7.53 & 8.0 & 10.34 & 9.14 \\
\hline T7 & $\mathbf{7 . 8 7}$ & 11.4 & 10.23 & 10.14 & 12.07 & 10.2 \\
\hline T8 & 4.67 & 7.07 & 7.74 & 8.14 & 8.26 & 7.87 \\
\hline T9 & 5.2 & 7.74 & 8.07 & 7.87 & 8.40 & 8.2 \\
\hline T test & $\mathbf{S}$ & $\mathbf{S}$ & $\mathbf{S}$ & $\mathbf{S}$ & $\mathbf{S}$ & $\mathbf{S}$ \\
\hline SEM ( \pm$)$ & 0.2645751 & 0.4009249 & 0.2581989 & 0.2966896 & 0.2792185 & 0.3124969 \\
\hline CD $(0.5 \%)$ & 0.5608993 & 0.8499607 & 0.5473816 & 0.6289819 & 0.5919432 & 0.6624935 \\
\hline
\end{tabular}

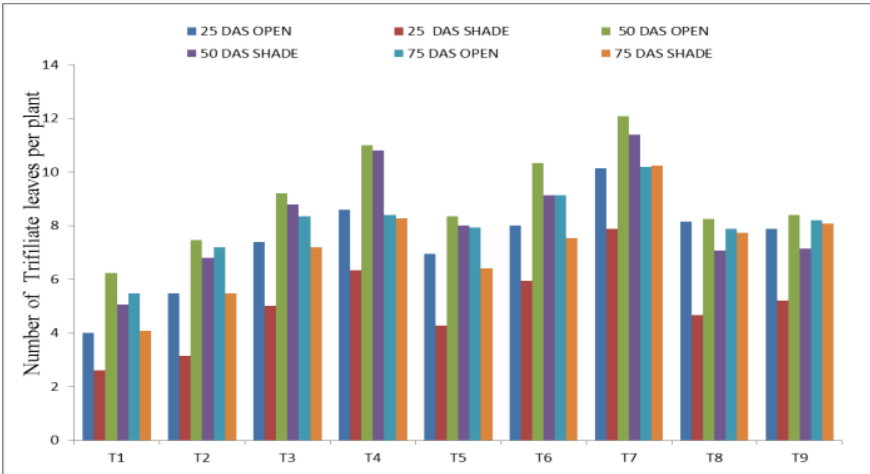

Fig. 2: Effect of N P K level in combination with Rhizobium and PSB culture number of trifoliate leaves per plant on of green gram under subabul based agroforestry system.

\section{Number of primary branches per plant}

From the Table 3 and Fig. 3 it was observed that the number of primary branches per plant was significantly influenced by different treatment combinations at different NPK level in combination with Rhizobium and PSB culture. At 25 DAS it was observed that different treatment combination did significantly affect the number of primary branches per plant. The maximum number of primary branches per plant was found in treatment $T_{7}$ (11.27) followed by treatment $T_{4}(9.6)$ in open condition and minimum number of number of primary branches per plant was observed in $\mathrm{T}_{1}(5.4)$.

Maximum number of primary branches per plant under subabul based agroforestry system is found in $\mathrm{T}_{7}$ (8.27), followed by $\mathrm{T}_{4}$ (7.0) and the minimum number of root nodules was observed in $\mathrm{T}_{1}$ (3.74). At $50 \mathrm{DAS}$, it was observed that different treatment combination significantly affect the number of primary branches per plant. The maximum number of primary branches per plant was found in treatment $\mathrm{T}_{7}$ (12.47) followed by treatment $\mathrm{T}_{4}(10.74)$ and minimum number of primary branches per plant was observed in $T_{1}$ (6.26). Maximum number of primary branches per plant under subabul based agroforestry system is found in $T_{7}$ (9.27), followed by $\mathrm{T}_{4}$ (8.6) and the minimum number of primary branches per plant was observed in $\mathrm{T}_{1}(4.87)$.

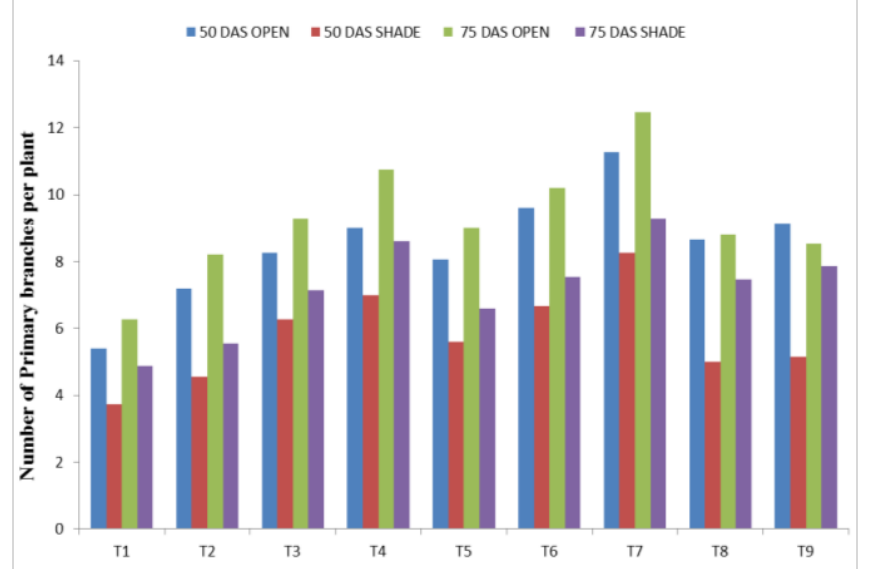

Fig. 3: Effect of N P K level in combination with Rhizobium and PSB culture Number of primary branches per plant on green gram under subabul based agroforestry system. 
Table 3. Effect of N P K level in combination with Rhizobium and PSB culture Number of primary branches per plant on green gram under subabul based agroforestry system.

\begin{tabular}{|c|c|c|c|c|}
\hline \multirow{3}{*}{ Treatment } & \multicolumn{4}{|c|}{ Number of primary branches per plant } \\
\hline & \multicolumn{2}{|l|}{ Shade condition } & \multicolumn{2}{|c|}{ Open condition } \\
\hline & 50 DAS & 75 DAS & 50 DAS & 75 DAS \\
\hline T1 & 3.74 & 4.87 & 5.4 & 6.26 \\
\hline $\mathbf{T 2}$ & 4.54 & 5.54 & 7.2 & 8.2 \\
\hline T3 & 6.27 & 7.14 & 8.27 & 9.27 \\
\hline T4 & 7.0 & 8.6 & 9.6 & 10.74 \\
\hline T5 & 5.6 & 6.6 & 8.07 & 9.0 \\
\hline T6 & 6.67 & 7.54 & 9.0 & 10.2 \\
\hline T7 & 8.27 & 9.27 & 11.27 & 12.47 \\
\hline T8 & 5.0 & 7.47 & 8.67 & 8.8 \\
\hline T9 & 5.14 & 7.87 & 9.13 & 8.54 \\
\hline T test & $\mathbf{S}$ & $\mathbf{S}$ & $\mathbf{S}$ & $\mathbf{S}$ \\
\hline $\operatorname{SEM}( \pm)$ & 0.2072751 & 0.255072 & 0.2860976 & 0.2806518 \\
\hline CD $(0.5 \%)$ & 0.4394232 & 0.5407527 & 0.606527 & 0.5949818 \\
\hline
\end{tabular}

\section{Number of secondary branches per plant}

From the Table 4 and Fig. 4 it was observed that the secondary branches per plant was significantly influenced by different treatment combinations at different NPK and combination with the Rhizobium and PSB culture. At 50
DAS, it was observed that different treatment combination significantly affect the number secondary branches per plant. The maximum number of secondary branches per plant was found in treatment $\mathrm{T}_{7}(6.2)$ followed by treatment $\mathrm{T}_{4}(5.27)$ and minimum number of secondary branches per plant was observed in $\mathrm{T}_{1}(2.54)$.

Table 4. Effect of Nitrogen, Phosphorus and Potassium in combination with Rhizobium and PSB culture on Number of secondary branches per plant of green gram under subabul based agroforestry system.

\begin{tabular}{|c|c|c|c|c|}
\hline \multirow{3}{*}{ Treatment } & \multicolumn{4}{|c|}{ Number of secondary branches per plant } \\
\hline & \multicolumn{2}{|c|}{ Shade condition } & \multicolumn{2}{|c|}{ Open condition } \\
\hline & 50 DAS & 75 DAS & 50 DAS & 75 DAS \\
\hline T1 & 1.27 & 2.87 & 2.54 & 3.8 \\
\hline $\mathbf{T 2}$ & 2.34 & 3.67 & 3.8 & 5.2 \\
\hline T3 & 3.27 & 4.4 & 4.54 & 7.67 \\
\hline $\mathbf{T 4}$ & 4.34 & 5.4 & 5.27 & 9.07 \\
\hline T5 & 3.0 & 4.0 & 3.0 & 5.54 \\
\hline T6 & 4.0 & 5.14 & 4.14 & 8.14 \\
\hline T7 & 6.07 & 7.34 & 6.2 & 10.34 \\
\hline T8 & 2.87 & 4.87 & 4.8 & 6.54 \\
\hline T9 & 3.14 & 5.14 & 4.93 & 7.87 \\
\hline T test & $\mathbf{S}$ & $\mathbf{S}$ & $\mathbf{S}$ & $\mathbf{S}$ \\
\hline $\operatorname{SEm}( \pm)$ & 0.2157388 & 0.2151657 & 0.1845916 & 0.3402976 \\
\hline $\operatorname{CD}(0.5 \%)$ & 0.4573662 & 0.4561514 & 0.3913343 & 0.721431 \\
\hline
\end{tabular}

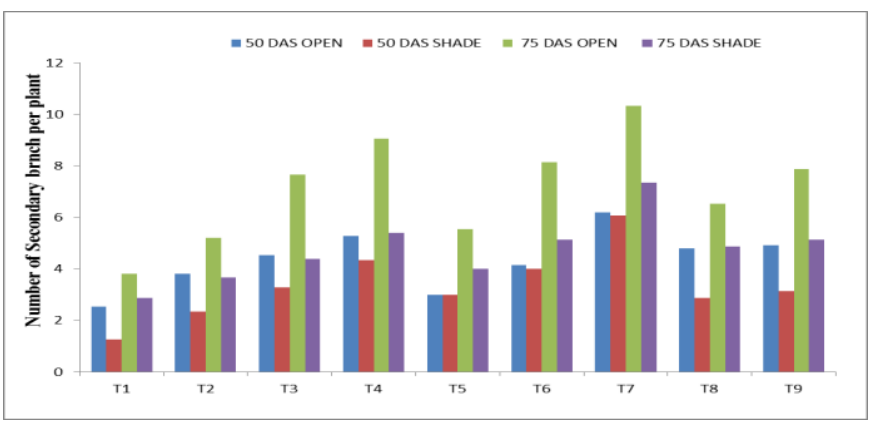

Fig. 4: Effect of NPK level in combination with Rhizobium and PSB culture on Number of secondary branches per plant of green gram under Subabul based Agroforestry system.
Maximum number of secondary branches per plant under subabul based agroforestry system is found in $\mathrm{T}_{7}$ (6.07), followed by $\mathrm{T}_{4}$ (4.34) and the minimum number of secondary branches per plant was observed in $\mathrm{T}_{1}$ (1.27). At 75 DAS, it was observed that different treatment combination significantly affect the number of secondary branches per plant. The maximum number of secondary branches per plant was found in treatment $T_{7}$ (10.34) followed by treatment $T_{4}(9.07)$ and minimum number of secondary branches per plant was observed in $\mathrm{T}_{1}$ (3.8). Maximum number of secondary branches per plant under subabul based agroforestry system is found 
in $\mathrm{T}_{7}$ (7.34), followed by $\mathrm{T}_{4}(5.4)$ and the minimum secondary branches per plant was observed in $\mathrm{T}_{1}(2.87)$.

\section{Pods length $(\mathrm{cm})$}

From the table 5 and Fig. 5 it was observed that the pods length (cm.) plant was significantly influenced by different treatment combinations at different N P K level and combination with the Rhizobium and PSB culture.
It was observed that different treatment combination significantly affect the pods length. The maximum pods length $(\mathrm{cm})$ was found in treatment $\mathrm{T}_{7}(9.66 \mathrm{~cm}$. followed by treatment $\mathrm{T}_{4}(8.36 \mathrm{~cm})$ and minimum pods length $(\mathrm{cm})$ was observed in $T_{1}(5.90 \mathrm{~cm})$. Maximum pods length $(\mathrm{cm})$ under subabul based agroforestry system is found in $T_{7}(9.16 \mathrm{~cm})$, followed by $\mathrm{T}_{4}(8.13$ $\mathrm{cm})$ and the minimum pods length $(\mathrm{cm})$ was observed in $\mathrm{T}_{1}(5.96 \mathrm{~cm})$.

Table 5: Effect of N P K level in combination with Rhizobium and PSB culture on Pods length $(\mathrm{cm})$ of green gram under Subabul based Agroforestry system.

\begin{tabular}{lll}
\hline \multirow{2}{*}{ Treatment } & Pods length $(\mathbf{c m})$ & \\
\cline { 2 - 3 } & Shade condition & Open condition \\
\hline T1 & $\mathbf{5 . 9 6}$ & $\mathbf{5 . 9 0}$ \\
T3 & 6.13 & 6.94 \\
T4 & 7.04 & 7.32 \\
T5 & 8.13 & $\mathbf{8 . 3 6}$ \\
T6 & 6.54 & 7.01 \\
T7 & 7.52 & 7.64 \\
T8 & $\mathbf{9 . 1 6}$ & $\mathbf{9 . 6 6}$ \\
T9 & 7.83 & 7.64 \\
T test & 7.98 & 8.08 \\
SEm $( \pm)$ & $\mathbf{S}$ & $\mathbf{S}$ \\
CD $(0.5 \%)$ & $\mathbf{0 . 1 6 0 1 9 6 6}$ & $\mathbf{0 . 2 5 6 1 0 0 9}$ \\
\hline
\end{tabular}

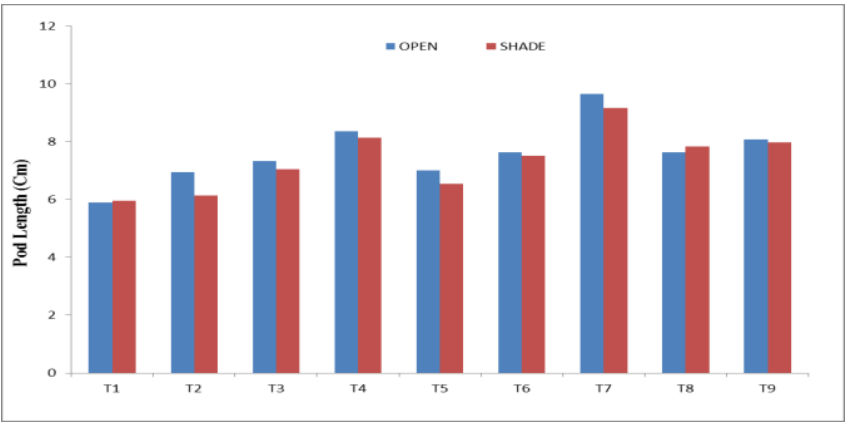

Fig. 5: Effect of N P k in combination with Rhizobium and PSB culture on Pods length $(\mathrm{cm}$.) of green gram under Subabul based Agroforestry system.

\section{Conclusion}

The present trail concluded that the observations obtained during the study that treatment $\mathrm{T}_{7} \mathrm{~N} 30 \mathrm{P} 30$ $\mathrm{K} 15+$ Rhizobium+PSB culture emerged as the most superior over all the other NPK level with regard to its growth performance both in open condition and under subabul based agroforestry system. So this N P K level with Rhizobium and PSB culture of green gram is highly recommended for cultivation under Subabul based Agroforestry system during summer season in Allahabad conditions.

\section{Conflict of interest statement}

Authors declare that they have no conflict of interest.

\section{Acknowledgement}

The authors are thankful to School of Forestry and Environment, SHIATS, Allahabad, UP, India for providing the experimentation site at Forest Nursery, supported during experiment and encouraged for such research. The help extended by the outside scientific community to this study in various ways is also acknowledged.

\section{References}

Hussain, M. S., Karim, M. F., Biswas, P. K., Kawochar, M. A., Islam, M. S., 2011. Effect of Rhizobium inoculation and fertilization on the yield and yield components of mungbean. J. Expt. Biosci. 2(1), 4667.

Khurana, A.L., Dudeja, S.S., 1997. Biological Nitrogen Fixation Technology for Pulses Production in India. Indian Institute of Pulses Research, Kanpur, India.

Nair, P.K.R., 1979. Classification of agroforestry 
systems. Agrofor. Syst. 3, 97-128.

Nutman, P. S., 1969. Genetics of symbiosis and nitrogen fixation in legumes. Proc. Roy. Soc. B, 172, 417-438.

Subba Rao, N. S., 1986. Phosphate Solubilization by Soil Micro Organisms. In: Advances in Agricultural
Microbiology (Ed.: Subba Rao, N.S.). Oxford and IBH, New Delhi. pp.295-303.

Vessey, J.K., 2003. Plant growth promoting rhizobacteria as biofertilizers. Plant Soil. 255, 571586.

\section{How to cite this article:}

Chauhan, D. K., Umrao, R., 2017. Effect of different levels of NPK in combination with Rhizobium and PSB culture on growth performance of green gram (Vigna radiata L. Wilczek) under subabul (Leucaena leucocephala) based agrisilviculture systems. Int. J. Curr. Res. Biosci. Plant Biol. 4(7), 112-118.

doi: https://doi.org/10.20546/ijcrbp.2017.407.014 